\title{
Emeralds from the Delbegetey deposit (Kazakhstan): mineralogical characteristics and fluid-inclusion study
}

\author{
E. V. Gavrilenko ${ }^{1,2, *}$, B. Calvo Pérez ${ }^{3}$, R. Castroviejo Bolibar ${ }^{3}$ and D. García del Amo ${ }^{1}$ \\ ${ }^{1}$ Department of Analytical Sciences, Spain's National Distance Education University (UNED), Senda del Rey 9 , \\ 28040, Madrid, Spain \\ ${ }^{2}$ Spanish Gemological Institute, Víctor Hugo 1, 28004 Madrid, Spain \\ ${ }^{3}$ Madrid School of Mines, Polytechnic University of Madrid, Ríos Rosas 21, 28003, Madrid, Spain
}

\section{ABSTRACT}

The aim of this study is to provide the first detailed mineralogical and fluid-inclusion description of emeralds from the Delbegetey deposit (Kazakhstan). The characteristic features of Delbegetey emeralds are established: they have dissolution figures on crystal faces, bluish colour and distinct colour zoning; the refractive indices are $\omega=1.566-1.570, \varepsilon=1.558-1.562$, and the specific gravity is $2.65 \pm 0.005$, relatively low for natural emeralds; they have very small concentrations of the impurities $(\mathrm{Fe}, \mathrm{Mg}, \mathrm{Na}$ and others) typical of other emeralds, and contain $\mathrm{Cr}$ and $\mathrm{V}$; there is a significant preponderance of vapour in fluid inclusions of all types and there is liquid-to-vapour homogenization of primary fluid inclusions (at $395-420^{\circ} \mathrm{C}$ ). The lattice oxygen isotope composition data obtained $\left(\delta^{18} \mathrm{O}\right.$ SMOW value of $11.3 \%$ ) situate the deposit within the range characteristic of other granite-related emerald deposits. Emerald crystallization took place in low-density $\left(0.40-0.55 \mathrm{~g} / \mathrm{cm}^{3}\right)$ aqueous fluid, with the following chemical composition (mol.\%): 75.6-97.4 $\mathrm{H}_{2} \mathrm{O}, 0.0-18.4 \mathrm{CO}_{2}, 0.0-0.9 \mathrm{CH}_{4}$, and 4.06-9.65 wt.\% $\mathrm{NaCl}$ equiv. salinity. According to the calculated isochores, the pressure of formation of the Delbegetey emeralds can be estimated at 570-1240 bar.

\section{Introduction}

AT present, there are two known sites where emeralds occur in Kazakhstan: Kuu Yuzhnoe and Delbegetey. These are situated in the central and northeastern parts of the country, respectively (Fig. 1). At both sites, emerald mineralization is associated with granite intrusions found in various metamorphic and sedimentary rocks. Most of the green beryls and emeralds originating in the quartz veins of Kuu Yuzhnoe are not of gem quality, and this locality has no commercial importance. In contrast, the Delbegetey deposit has been exploited for emeralds since the early 1990s, and has produced a certain amount of gem material.

Nevertheless, the characteristics of emeralds from this locality have not been described in the literature. The object of this study is to provide a detailed mineralogical and fluid-inclusion description of the Delbegetey emeralds, based on 12 samples donated for this purpose. For comparison, a representative collection of emeralds from other deposits was also studied, together with synthetically grown emeralds.

The results of this study provide a series of characteristic features which make it possible to differentiate unequivocally between the Delbegetey emeralds and other natural and synthetic samples. Furthermore, the study of fluid inclusions allows us to characterize the range of pressure-temperature conditions of the Delbegetey emerald formation.

\section{Geological setting}

The Delbegetey deposit is situated in the Charsky region, $\sim 100 \mathrm{~km}$ to the south of Semeytau 


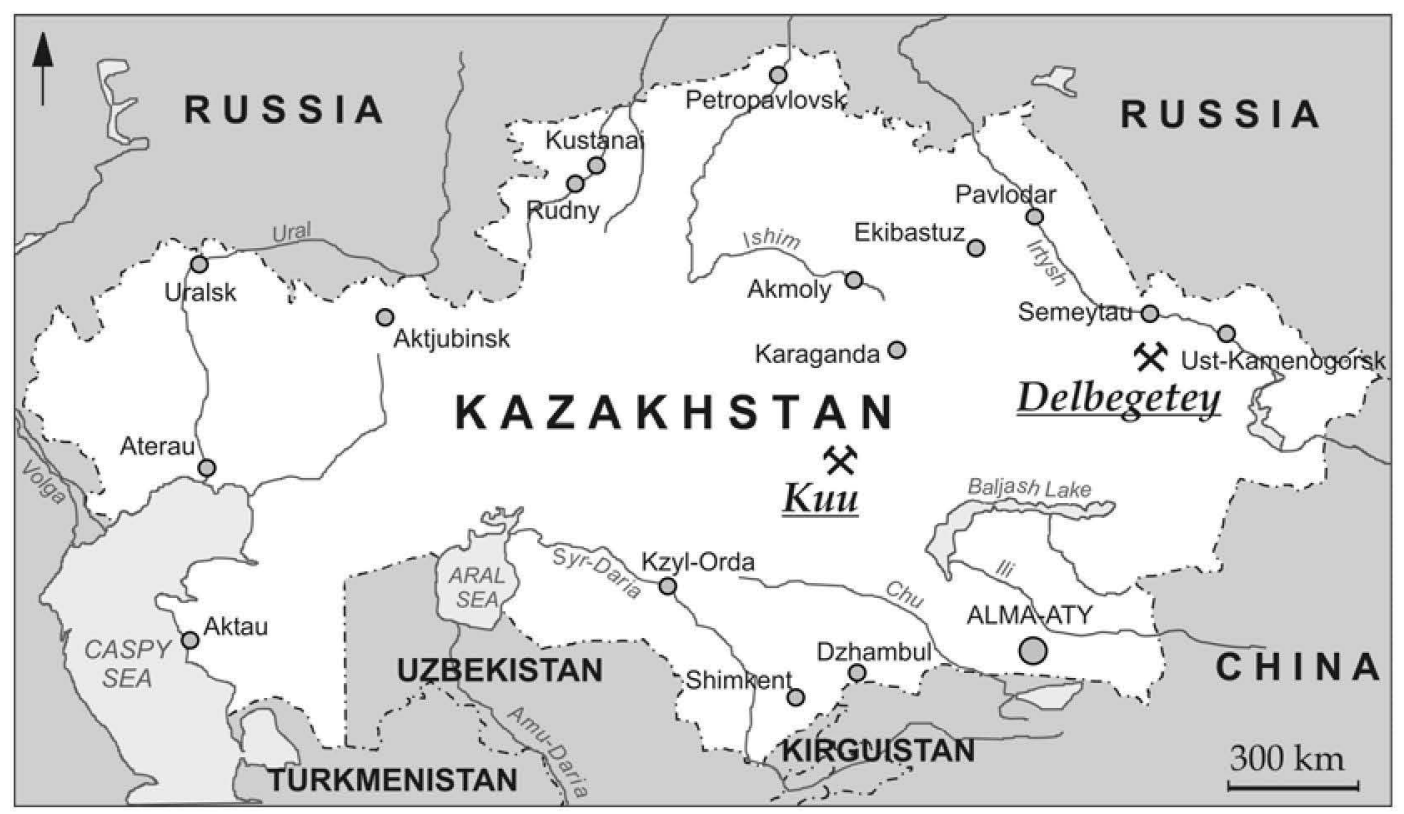

FIG. 1. Location of Delbegetey and Kuu Yuzhnoye emerald occurrences in Kazakhstan.

(formerly, Semipalatinsk). Here, emerald mineralization is closely associated with the Delbegetey granite pluton. This pluton intrudes Carboniferous sandstones at the intersection of the NE ZapadnoKolbinsky fault with a transform fault trending towards the NW. The Delbegetey pluton exhibits a circular shape at the current level of erosion, and has steeply dipping contacts $\left(\sim 40^{\circ}\right)$. The pluton comprises various types and facies of granites. Porphyritic biotite granite represents the earliest intrusive phase to crystallize; it makes up $~ 80 \%$ of the total volume of the pluton. More leucocratic and homogeneous biotite granite represents a somewhat younger facies, which is cut by still younger aplite veins. The country rocks were transformed into hornfels on contact with granites (Vinogradova, 1996).

The Delbegetey emerald deposit is confined to the southern contact of the granite pluton, and associated with an $\mathrm{E}-\mathrm{W}$-trending fracture zone which extends westward for $>1300 \mathrm{~m}$, linking Delbegetey with another granite intrusion, the Chernogorskiy pluton. This fracture zone is $2-15 \mathrm{~m}$ thick, and has an almost vertical dip. The wall-rocks along this zone suffered several metasomatic events (silicification, tourmalinization and actinolitization) which resulted in the development of a system of branching veins, composed mainly of quartz, muscovite, tourma- line, fluorite and beryl. Emerald is most commonly found in segregations (nests) of mica greisen and in quartz-muscovite veinlets. Some greisen nests reach $0.5 \mathrm{~m}$ across, and the veinlets range from 5 to $20 \mathrm{~cm}$ thick. The largest emerald crystals found are $15 \mathrm{~mm}$ long, but most are smaller in size. Those crystals having the most intensive green colouring occur in greisen nests containing blue fluorite.

As with the majority of known emerald sites, Delbegetey is genetically associated with granitic magmatism. On the other hand, Delbegetey has the quite unusual geological setting of being located in sedimentary rocks. Most other deposits (except for the Colombian emeralds, for example) tend to be associated with metamorphic and/or intrusive ultramafic rocks, enriched in $\mathrm{Cr}$. Hence, the $\mathrm{Cr}$ source responsible for the green colour of Delbegetey emeralds remains unspecified. However, a likely source may be a melange zone, containing olistostromes of serpentinites, that underlies the Carboniferous sedimentary sequence (E.A. Vinogradova, pers. comm.).

\section{Sample description}

Twelve crystals of emerald from the Delbegetey deposit were studied in the present work. All crystals have a prismatic habit and range from 3.4 
to $8.0 \mathrm{~mm}$ long and are $2.6-4.2 \mathrm{~mm}$ thick (Fig. 2). The dominant crystallographic forms are prismatic $\{10 \overline{1} 0\}$ and pinacoidal $\{0001\}$, although poorly developed bipyramidal faces $\{11 \overline{2} 1\}$ and $\{10 \overline{1} 1\}$ - were also observed. The prism and bipyramidal faces are covered with numerous dissolution pits and furrows. These features are less common on the surface of the pinacoid which shows some hexagonal growth pyramids.

To study the gemmological characteristics of the Delbegetey emeralds, four crystals were polished, obtaining cut stones which ranged from 0.10 to 0.15 ct.

\section{Experimental techniques}

The absorption spectra were recorded from the polished plates cut parallel and perpendicular to the $c$ axis of one Delbegetey emerald crystal, in a range from 300 to $1000 \mathrm{~nm}$, using a Shimadzu UV-160 spectrometer. Spectra of other crystals were also recorded without special sample preparation. In addition, all the stones were studied using a gemmological hand-held Beck prism spectroscope.

Refractive indices were determined from seven samples using a gemmological refractometer (KRUSS). For the specific gravity measurement, the equilibration in high-density liquids and a Westphal balance were used. Long and short wave UV fluorescence ( 365 and $253.7 \mathrm{~nm}$ ) of the samples was observed using a standard gemmological UV lamp. X-ray powder-diffraction data were obtained using a DRON-2 diffractometer ( $\mathrm{Co}-\mathrm{K} \alpha$ radiation, $\mathrm{Ge}$ internal standard).

The chemical composition of 10 samples of Delbegetey emerald was determined by electron microprobe WDS equipment Geol SX-8600. In addition, 47 other samples of natural and synthetic emeralds were analysed, using the same method and analytical procedure. Comparative samples included natural emeralds from a variety of deposits located in Colombia, Russia, Brazil, Zambia, Zimbabwe, Tanzania, Madagascar and Nigeria, as well as synthetic samples grown by hydrothermal and flux methods. In total, 114 microprobe analyses were carried out.

The oxygen isotopic composition of one Delbegetey emerald sample was studied. Framework oxygen extraction was carried out, using standard techniques, with $\mathrm{BrF}_{5}$ as the reagent (Clayton and Mayeda, 1963), and following the procedure described by Giuliani et al. (1998).

For the fluid inclusion study, four double polished plates were prepared. Faceted stones were also used to study the types and spatial relations of fluid inclusions present in the emeralds. Microthermometric measurements were carried out using the heating-freezing stage designed by T.J. Reynolds (Fluid Inclusion Co., USA) and synthetic calibration standards (T-Calibration Standards by SYN-FLINC). In inclusions containing liquid $\mathrm{CO}_{2}$, after rapid

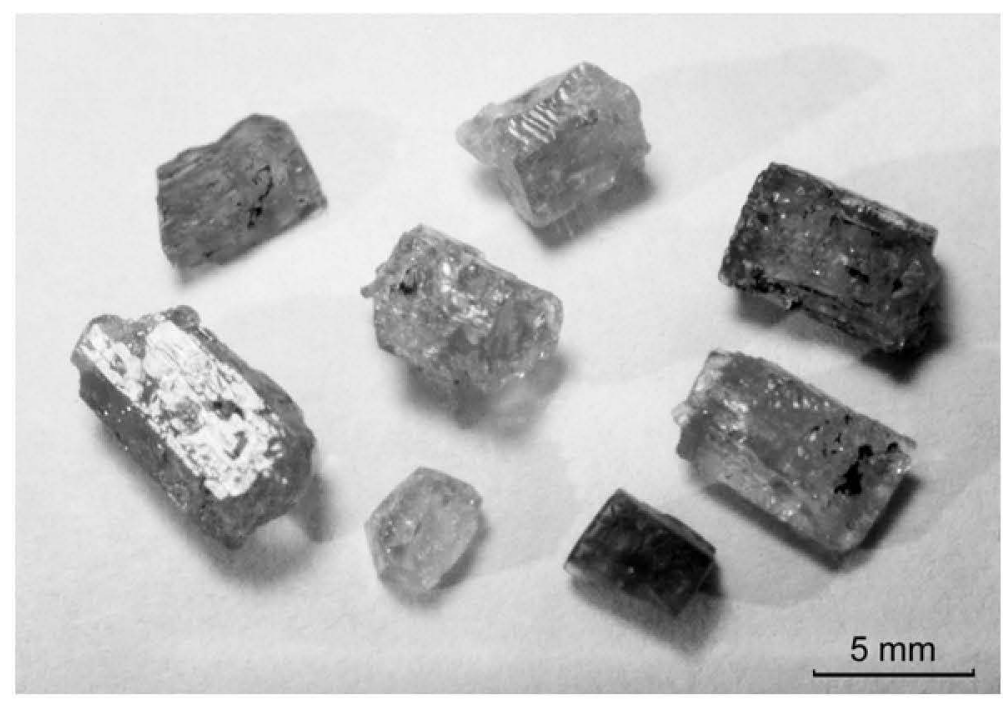

Fig. 2. Crystal morphology of some of the Delbegetey emeralds studied. 
freezing down to -110 to $-120^{\circ} \mathrm{C}\left(\mathrm{CO}_{2}\right.$ liq freezing), the following phase changes and temperatures were measured: melting of $\mathrm{CO}_{2 \text { solid }}\left(\sim-56.8^{\circ} \mathrm{C}\right)$; ice melting $\left(\sim-4^{\circ} \mathrm{C}\right)$; melting of clathrates $\left(\sim 6^{\circ} \mathrm{C}\right)$; homogenization of $\mathrm{CO}_{2 \text { liq }}+\mathrm{CO}_{2 \text { vapour }} \rightarrow$ vapour (always to vapour, at $\sim 20^{\circ} \mathrm{C}$ ); total homogenization of inclusion liquid + vapour $\rightarrow$ vapour (at between 395 and $430^{\circ} \mathrm{C}$ ). For inclusions containing only aqueous liquid and vapour phases, ice melting and homogenization temperatures were measured.

Mineral inclusions were analysed in polished and cut samples using an Hitachi S-3000N scanning electron microscope with EDS detector. Semi-quantitative analysis of inclusions was carried out, using a Quantax 1.2 (RÖNTEC $\mathrm{GmbH}$, Germany) program.

\section{Results}

\section{Colour}

The intensity of the colours in the samples studied is quite variable, from pale to strong. Some palecoloured crystals should be classified as bluishgreen beryls and others have sufficient colour intensity to be classified as emeralds. Characteristic $\mathrm{Cr}$ absorption lines were observed using a hand-held gemmological spectroscope on these intense green samples. All crystals have a strongly bluish hue, slightly different from that observed in emeralds from other localities worldwide. The crystals show a strong pleochroism, from bluish-green $(\varepsilon)$ to green $(\omega)$. All crystals show colour zoning parallel to the prism and pinacoid faces. Individual colour zones may have either abrupt or gradational boundaries. Within the dark zones, an intricate micro-zoning was observed.

Colour was also determined for the cut stones in accordance with the Gemological Institute of America (GIA) colour stone gradation rules. Estimation of colour is based on the Munsell colour system (Munsell, 1988). Using GIA GemSet $\AA$ colour samples, three components of colour (hue, tone and saturation) were estimated for each stone, providing the following colour characteristics: vstbG $3 / 3$ to vstbG $2 / 2$.

\section{Absorption spectra}

Absorption spectra obtained for one Delbegetey sample are shown in Fig. 3.

The spectra demonstrate several features that can be observed in emeralds with different origins. These features include: two broad absorption bands centred at $\sim 430 \mathrm{~nm}$ and $610 \mathrm{~nm}$, corresponding to spin-permitted $d-d$ electron transitions in scattered outer shells of $\mathrm{Cr}^{3+}$ in the $\mathrm{Al}$ position; and three sharp absorption lines at 636, 657 and $680 \mathrm{~nm}$, observed best in spectra obtained from the sections taken parallel to the $c$ axis, and attributed to spin-prohibited electron transitions in $\mathrm{Cr}^{3+}$. These three absorption lines - which were also observed in the emeralds studied using a hand-held gemmological spectroscope - are absent from the spectra of pure V emeralds (Wood and Nassau, 1968).

Another important characteristic of the optical spectra of the emerald studied is a broad absorption band centred at $810 \mathrm{~nm}$, associated

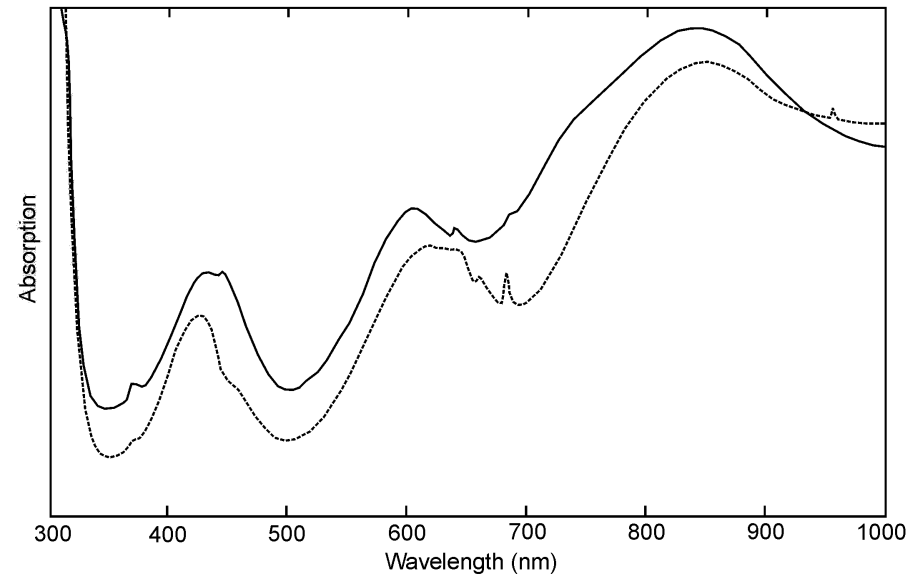

FIG. 3. Delbegetey emerald absorption spectra (full lines $-c$-axis perpendicular section, dashed lines $-c$-axis parallel section). 
TABle 1. Physical properties of the Delbegetey emeralds.

\begin{tabular}{lcccccc}
\hline \multirow{2}{*}{ Property } & \multicolumn{2}{c}{ UV fluorescence } & \multicolumn{2}{c}{ Refractive indices } & Birefringence & Specific gravity \\
& $365 \mathrm{~nm}$ & $253.7 \mathrm{~nm}$ & $\omega$ & $\varepsilon$ & & \\
\hline Description & weak red & inert & $1.566-1.570$ & $1.558-1.562$ & 0.008 & $2.65 \pm 0.005$ \\
Samples studied & 12 & 12 & 7 & 7 & 7 & 2 \\
& & & & & & \\
\hline
\end{tabular}

with the presence of small amounts of $\mathrm{Fe}^{2+}$, both in the $\mathrm{Al}$ position - $\omega$-oriented spectra - and in the structure canals $-\varepsilon$-oriented spectra $-($ Wood and Nassau, 1968). Some of the Delbegetey samples exhibit no absorption in this region, but most of the samples do show this characteristic band.

The sharp absorption band in the near-IR part of the spectrum (956 nm, Fig. 3) obtained from the section parallel to the $c$ axis corresponds to Type I water molecules (Wood and Nassau, 1968). The presence of this water type in the structure channels is normal for these very lowalkali emeralds.

\section{Other physical properties}

The results of the determination of refractive indices, birefringence, specific gravity and UV luminescence of the Delbegetey emeralds are shown in Table 1. Weak long-wave UV red fluorescence, observed in the samples studied, is normal for low-Fe natural and synthetic emeralds. A comparison of the refractive indices and specific gravity values obtained with those typical of other natural and synthetic emeralds (Schwarz, 1987; Gavrilenko and Dashevsky, 1998) shows that the refractive indices and specific gravity of the Delbegetey samples are quite low, lower, in fact, than those of most other naturally occurring emeralds. The latter usually present values in the range of $1.570-1.600$, for ordinary ray refractive index, and $2.67-2.79$ for specific gravity. The small values of these constants, obtained for the Delbegetey emeralds, are more typical of synthetic flux-grown emeralds. Some possible reasons for this particular characteristic in the emeralds studied are discussed below.

\section{$X$-ray diffraction}

An X-ray diffraction study gave the following unit-cell dimensions for one of the Delbegetey crystals: $a=9.218(1) \AA, c=9.201(1) \AA, V=$ 677.1(3) $\AA^{3}$. These values are discussed below in relation to the crystal chemical characteristics and types of beryls proposed by Aurisicchio et al. (1988).

\section{Chemical composition}

Medium chemical compositions for the ten Delbegetey emeralds are given in Table 2, based on three microprobe analyses for each sample. The table also contains data variation for each component, based on 35 microprobe analyses of the Delbegetey emeralds, and the calculation of atoms per formula unit (a.p.f.u.) values.

Table 3 also contains microprobe analysis results of some reference samples of natural emeralds from other deposits, and synthetic samples. Figure 4 shows the relative concentrations of three major chromophore components in the Delbegetey emeralds, and Fig. 5 shows the relationship between the $\mathrm{Al}$ content and the sum of octahedral substitution components in emeralds, based on microprobe analysis data. The

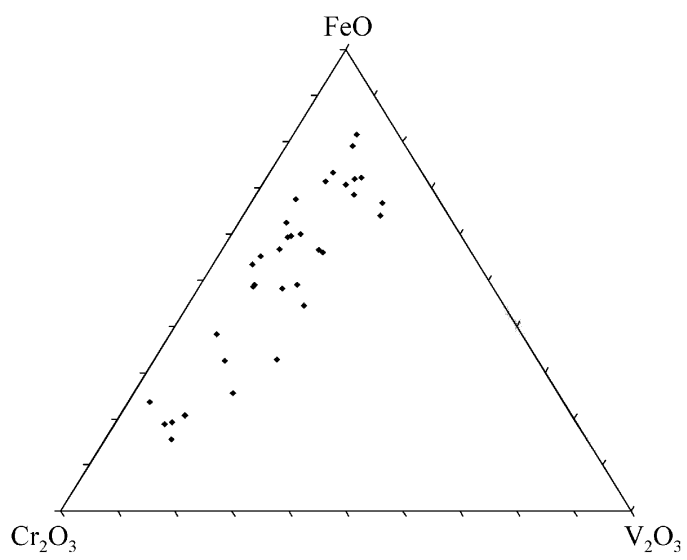

FIG. 4. Weight proportions of free major emerald chromophore oxides in the composition of Delbegetey emeralds (based on 35 microprobe analyses of ten samples). 
TABLE 2. Microprobe data (wt.\%) and a.p.f.u. values calculated for ten Delbegetey emeralds (1-1 to 1-10; medium values calculated on the basis of three microprobe analyses of each sample).

\begin{tabular}{|c|c|c|c|c|c|c|c|c|c|c|c|c|c|}
\hline & \multicolumn{13}{|c|}{ Delbegetey emeralds } \\
\hline & $1-1$ & $1-2$ & $1-3$ & $1-4$ & $1-5$ & $1-6$ & $1-7$ & $1-8$ & $1-9$ & $1-10$ & $(\min -\max )$ & aver. & st.dev. \\
\hline $\mathrm{SiO}_{2}$ & 66.15 & 66.12 & 66.65 & 66.03 & 66.18 & 66.23 & 66.49 & 64.99 & 66.71 & 64.53 & $(63.16-67.01)$ & 65.99 & 0.87 \\
\hline $\mathrm{Al}_{2} \mathrm{O}_{3}$ & 17.56 & 18.56 & 18.81 & 19.02 & 18.95 & 18.69 & 19.34 & 18.94 & 19.32 & 19.24 & $(17.48-19.93)$ & 18.87 & 0.62 \\
\hline $\mathrm{Cr}_{2} \mathrm{O}_{3}$ & 1.08 & 0.23 & 0.04 & 0.05 & 0.20 & 0.34 & 0.07 & 0.20 & 0.09 & 0.67 & $(0.02-1.23)$ & 0.29 & 0.34 \\
\hline $\mathrm{V}_{2} \mathrm{O}_{3}$ & 0.15 & 0.12 & 0.07 & 0.04 & 0.06 & 0.09 & 0.05 & 0.06 & 0.03 & 0.12 & $(0.02-0.19)$ & 0.07 & 0.05 \\
\hline $\mathrm{FeO}$ & 0.30 & 0.24 & 0.25 & 0.25 & 0.29 & 0.26 & 0.22 & 0.36 & 0.15 & 0.20 & $(0.13-0.37)$ & 0.25 & 0.07 \\
\hline $\mathrm{MgO}$ & 0.03 & 0.02 & 0.05 & 0.07 & 0.06 & 0.04 & 0.05 & 0.07 & 0.03 & 0.03 & $(0.01-0.10)$ & 0.05 & 0.02 \\
\hline $\mathrm{MnO}$ & 0.01 & 0.01 & 0.00 & 0.01 & 0.01 & 0.00 & 0.00 & 0.01 & 0.01 & 0.01 & $(0.00-0.02)$ & 0.01 & 0.01 \\
\hline $\mathrm{Na}_{2} \mathrm{O}$ & 0.02 & 0.05 & 0.07 & 0.03 & 0.04 & 0.06 & 0.04 & 0.05 & 0.02 & 0.05 & $(0.01-0.08)$ & 0.04 & 0.02 \\
\hline $\mathrm{K}_{2} \mathrm{O}$ & 0.02 & 0.01 & 0.01 & 0.01 & 0.02 & 0.01 & 0.00 & 0.03 & 0.01 & 0.00 & $(0.00-0.05)$ & 0.01 & 0.01 \\
\hline Total & 85.32 & 85.35 & 85.95 & 85.50 & 85.81 & 85.72 & 86.27 & 84.71 & 86.37 & 84.84 & $(82.59-86.84)$ & 85.59 & 0.83 \\
\hline $\begin{array}{l}\text { a.p.f.u. } \\
\text { Si }\end{array}$ & 6.01 & 5.98 & 5.98 & 5.96 & 5.96 & 5.97 & 5.95 & 5.94 & 5.96 & 5.89 & $(5.89-6.01)$ & 5.96 & 0.03 \\
\hline A1 & 1.88 & 1.98 & 1.99 & 2.02 & 2.01 & 1.99 & 2.04 & 2.04 & 2.03 & 2.07 & $(1.88-2.07)$ & 2.01 & 0.05 \\
\hline $\mathrm{Cr}$ & 0.08 & 0.02 & 0.00 & 0.00 & 0.01 & 0.02 & 0.00 & 0.01 & 0.01 & 0.05 & $(0.00-0.08)$ & 0.02 & 0.03 \\
\hline V & 0.01 & 0.01 & 0.01 & 0.00 & 0.00 & 0.01 & 0.00 & 0.00 & 0.00 & 0.01 & $(0.00-0.01)$ & 0.01 & 0.01 \\
\hline $\mathrm{Fe}^{2+}$ & 0.02 & 0.02 & 0.02 & 0.02 & 0.02 & 0.02 & 0.02 & 0.03 & 0.01 & 0.01 & $(0.01-0.03)$ & 0.02 & 0.01 \\
\hline $\mathrm{Mg}$ & 0.00 & 0.00 & 0.01 & 0.01 & 0.01 & 0.01 & 0.01 & 0.01 & 0.00 & 0.00 & $(0.00-0.01)$ & 0.01 & 0.01 \\
\hline $\mathrm{Mn}$ & 0.00 & 0.00 & 0.00 & 0.00 & 0.00 & 0.00 & 0.00 & 0.00 & 0.00 & 0.00 & $(0.00-0.00)$ & 0.00 & 0.00 \\
\hline Total VI & 1.99 & 2.03 & 2.03 & 2.05 & 2.05 & 2.05 & 2.07 & 2.09 & 2.05 & 2.14 & $(1.99-2.14)$ & 2.06 & 0.04 \\
\hline $\mathrm{Na}$ & 0.00 & 0.01 & 0.01 & 0.01 & 0.01 & 0.01 & 0.01 & 0.01 & 0.00 & 0.01 & $(0.00-0.01)$ & 0.01 & 0.00 \\
\hline $\mathrm{K}$ & 0.00 & 0.00 & 0.00 & 0.00 & 0.00 & 0.00 & 0.00 & 0.00 & 0.00 & 0.00 & $(0.00-0.00)$ & 0.00 & 0.00 \\
\hline Total $\mathbf{R f}$ & 0.00 & 0.01 & 0.01 & 0.01 & 0.01 & 0.01 & 0.01 & 0.01 & 0.00 & 0.01 & $(0.00-0.01)$ & 0.01 & 0.00 \\
\hline
\end{tabular}

\begin{tabular}{|c|c|c|c|c|c|c|c|c|c|c|c|c|c|c|}
\hline & \multicolumn{9}{|c|}{ Other natural emeralds } & \multicolumn{3}{|c|}{ Synt. flux grown } & \multicolumn{2}{|c|}{ Synt. hydr. } \\
\hline & $2-1$ & $2-2$ & $2-3$ & $2-4$ & $2-5$ & $2-6$ & $2-7$ & $2-8$ & $2-9$ & $3-1$ & $3-2$ & $3-3$ & 4-1 & $4-2$ \\
\hline $\mathrm{SiO}_{2}$ & 62.23 & 61.64 & 62.72 & 62.66 & 62.86 & 63.50 & 62.42 & 63.71 & 63.42 & 65.19 & 64.73 & 64.49 & 63.73 & 63.58 \\
\hline $\mathrm{Al}_{2} \mathrm{O}_{3}$ & 15.46 & 13.70 & 15.82 & 15.48 & 16.35 & 18.22 & 16.24 & 18.24 & 19.29 & 19.89 & 20.28 & 20.16 & 16.77 & 17.42 \\
\hline $\mathrm{Cr}_{2} \mathrm{O}_{3}$ & 0.58 & 0.72 & 0.37 & 0.59 & 0.24 & 0.53 & 0.16 & 0.27 & 0.12 & 0.71 & 0.74 & 0.80 & 0.37 & 0.47 \\
\hline $\mathrm{V}_{2} \mathrm{O}_{3}$ & 0.03 & 0.06 & 0.03 & 0.04 & 0.00 & 0.06 & 0.02 & 0.40 & 0.18 & 0.06 & 0.01 & 0.11 & 0.00 & 0.01 \\
\hline $\mathrm{FeO}$ & 0.49 & 1.08 & 0.95 & 0.34 & 0.51 & 0.78 & 0.90 & 0.10 & 0.69 & 0.04 & 0.10 & 0.04 & 2.73 & 2.35 \\
\hline $\mathrm{MgO}$ & 2.55 & 2.77 & 2.06 & 2.44 & 2.12 & 0.64 & 1.76 & 0.78 & 0.05 & 0.19 & 0.00 & 0.01 & 0.14 & 0.06 \\
\hline $\mathrm{MnO}$ & 0.00 & 0.00 & 0.00 & 0.00 & 0.00 & 0.00 & 0.00 & 0.00 & 0.00 & 0.00 & 0.00 & 0.00 & 0.04 & 0.01 \\
\hline $\mathrm{Na}_{2} \mathrm{O}$ & 1.05 & 1.50 & 1.15 & 1.00 & 1.08 & 0.24 & 1.28 & 0.46 & 0.03 & 0.03 & 0.03 & 0.00 & 0.02 & 0.02 \\
\hline $\mathrm{K}_{2} \mathrm{O}$ & 0.02 & 0.02 & 0.01 & 0.01 & 0.13 & 0.16 & 0.02 & 0.00 & 0.01 & 0.02 & 0.00 & 0.01 & 0.00 & 0.00 \\
\hline Total & 82.41 & 81.49 & 83.11 & 82.56 & 83.29 & 84.13 & 82.80 & 83.96 & 83.79 & 86.13 & 85.89 & 85.62 & 83.80 & 83.92 \\
\hline
\end{tabular}

Notes: Minimum, maximum and average contents are calculated for 35 analyses of ten Delbegetey samples. Calculation of a.p.f.u. values normalized to 15 oxygens (taking into account 3 a.p.f.u. of Be, not analysed). Comparative emerald samples: Natural: 2-1 Russia, Mariinskoye (formerly Malysheva); 2-2 Brazil, Santa Terezinha; 2-3 Zambia, Kitwe; 2-4 Zimbabwe, Sandawana; 2-5 Tanzania, Manyara; 2-6 Tanzania, Sumbawanga; 2-7 Madagascar, unknown; 2-8 Colombia, Muzo; 2-9 Nigeria, Jos; Synthetic: 3-1 Chatham flux grown; 3-2 Inamori flux grown; 3-3 Russian flux grown; 4-1, 4-2 Russian hydrothermal.

results of these microprobe analyses are discussed below.

Line-scanning and secondary-electron imagery indicate that the Delbegetey material shows some intra-crystalline variations in chemical composi- tion, principally with regard to $\mathrm{Cr}$ content. These variations are associated with regular growth zoning, together with a more complex, irregular zoning (Fig. 6). While regular straight-line zones are very common in emeralds from other deposits, 
TABLE 3. Microthermometric data for fluid inclusions of different types.

\begin{tabular}{|c|c|c|c|c|c|c|c|c|c|c|c|c|c|c|c|}
\hline \multirow[t]{2}{*}{ FIA } & \multirow[t]{2}{*}{$(n)$} & \multirow[t]{2}{*}{ Type } & \multirow{2}{*}{$\begin{array}{l}T_{\mathrm{mCO}} \\
\left({ }^{\circ} \mathrm{C}\right)\end{array}$} & \multirow{2}{*}{$\begin{array}{l}T_{\mathrm{m} \text { ice }} \\
\left({ }^{\circ} \mathrm{C}\right)\end{array}$} & \multirow{2}{*}{$\begin{array}{l}T_{\mathrm{m} \text { clthr }} \\
\left({ }^{\circ} \mathrm{C}\right)\end{array}$} & \multirow{2}{*}{$\begin{array}{l}T_{\mathrm{hCO}} \\
\left({ }^{\circ} \mathrm{C}\right)\end{array}$} & \multirow{2}{*}{$\begin{array}{l}T_{\mathrm{h}} \text { ot } \\
\left({ }^{\circ} \mathrm{C}\right)\end{array}$} & \multirow{2}{*}{$\begin{array}{l}V_{\text {vap }} \\
(\text { vol.\%) }\end{array}$} & \multirow{2}{*}{$\begin{array}{c}\text { Salinity } \\
\text { (wt.\% } \mathrm{NaCl} \text { equiv.) }\end{array}$} & \multirow{2}{*}{$\begin{array}{l}\text { Bulk density } \\
\left(\mathrm{g} / \mathrm{cm}^{3}\right)\end{array}$} & \multicolumn{5}{|c|}{ Bulk composition (mole fraction) } \\
\hline & & & & & & & & & & & $\mathrm{H}_{2} \mathrm{O}$ & $\mathrm{Na}^{+}$ & $\mathrm{Cl}^{-}$ & $\mathrm{CO}_{2}$ & $\mathrm{CH}_{4}$ \\
\hline \multicolumn{16}{|c|}{ Primary inclusions } \\
\hline I-1 & $(8)$ & P1 & & -3.0 & & & 408 & 67 & 5.01 & 0.50 & 0.970 & 0.015 & 0.015 & & \\
\hline $\mathrm{I}-2$ & (4) & P1 & -56.9 & -4.3 & 4.6 & 18.5 & 416 & 75 & 9.65 & 0.40 & 0.756 & 0.025 & 0.025 & 0.184 & 0.009 \\
\hline $\mathrm{I}-3$ & (4) & $\mathbf{P} 2$ & -56.8 & -3.9 & 5.6 & 17.5 & 398 & 72 & 8.10 & 0.42 & 0.787 & 0.021 & 0.021 & 0.163 & 0.007 \\
\hline \multicolumn{16}{|c|}{ Pseudosecondary inclusions } \\
\hline $\mathrm{I}-13$ & $(8)$ & PS1 & & -2.8 & & & 410 & 88 & 470 & 0.49 & 0.972 & 0.014 & 0.014 & & \\
\hline $\mathrm{I}-10$ & (6) & PS2 & & -2.6 & & & 415 & 68 & 4.38 & 0.46 & 0.974 & 0.013 & 0.013 & & \\
\hline II-1 & (10) & PS2 & & -3.7 & & & 414 & 84 & 6.08 & 0.51 & 0.962 & 0.019 & 0.019 & & \\
\hline II-2 & (6) & PS2 & & -2.4 & & & 405 & 86 & 4.06 & 0.49 & 0.974 & 0.013 & 0.013 & & \\
\hline III-1 & (11) & PS2 & -56.7 & -3.5 & 7.5 & 22 & 418 & 70 & 4.88 & 0.45 & 0.794 & 0.013 & 0.013 & 0.176 & 0.005 \\
\hline I-14 & (7) & PS3 & & -5.1 & & & 417 & 89 & 8.12 & 0.55 & 0.950 & 0.025 & 0.025 & & \\
\hline
\end{tabular}

Notes: Medium values for each fluid inclusion assemblage (FIA) are shown; $(n)-$ number of inclusions measured 


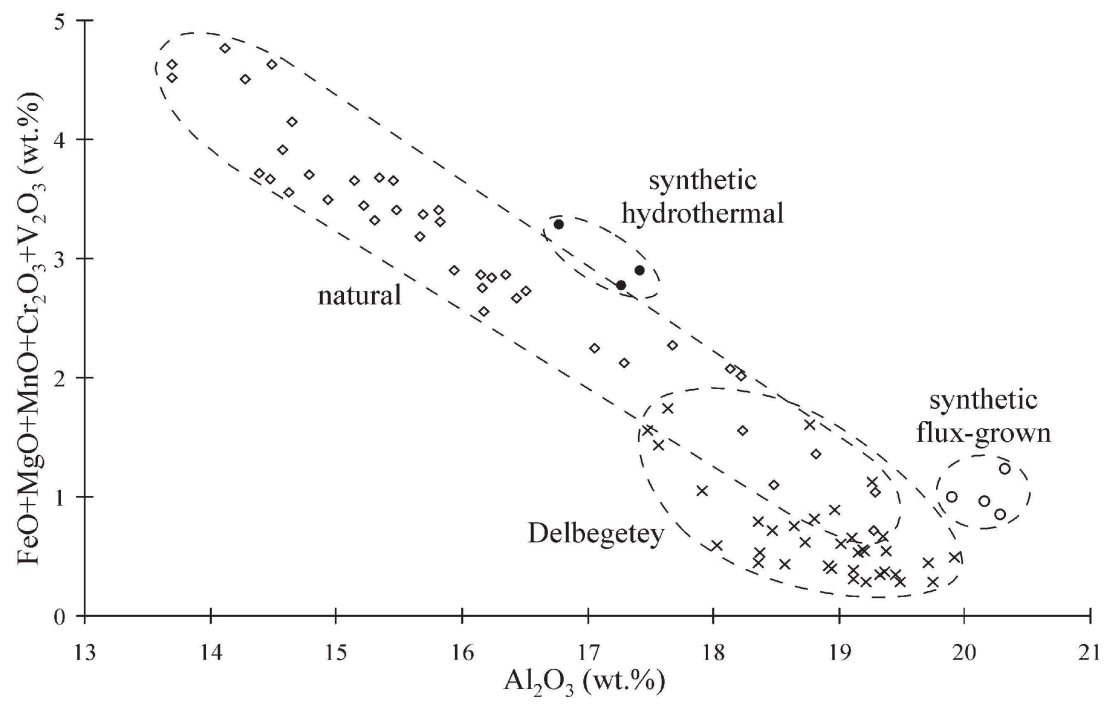

FIG. 5. Sum of octahedral substitution components $\left(\mathrm{FeO}+\mathrm{MgO}+\mathrm{MnO}+\mathrm{Cr}_{2} \mathrm{O}_{3}+\mathrm{V}_{2} \mathrm{O}_{3}\right)$ vs. $\mathrm{Al}_{2} \mathrm{O}_{3}$ content in Delbegetey emeralds compared with other natural and synthetic emeralds.

irregular growth zones appear to be typical of the emeralds studied, indicative, possibly, of a complex crystallization history, which may involve several dissolution and growth episodes.

\section{Oxygen isotopic composition}

A $\delta^{18} \mathrm{O}$ (SMOW) value of $11.3 \%$ was obtained for one Delbegetey emerald studied. This value is slightly higher than the general range for magmatic waters established by Sheppard (1986) Nevertheless, it falls within the range of $\delta^{18} \mathrm{O}$ values obtained for 14 comparison samples from typically magma-related Ural Mountains emeralds (9.3-11.7\%o, mean 10.9 $\pm 0.6 \%$ ) (Gavrilenko et al., 2001). In some other magma-related emerald deposits, even much higher $\delta^{18} \mathrm{O}$ values were found, falling in the isotopic compositional field typical of highly evolved peraluminous granites (Groat et al., 2002; Marshall et al., 2004).

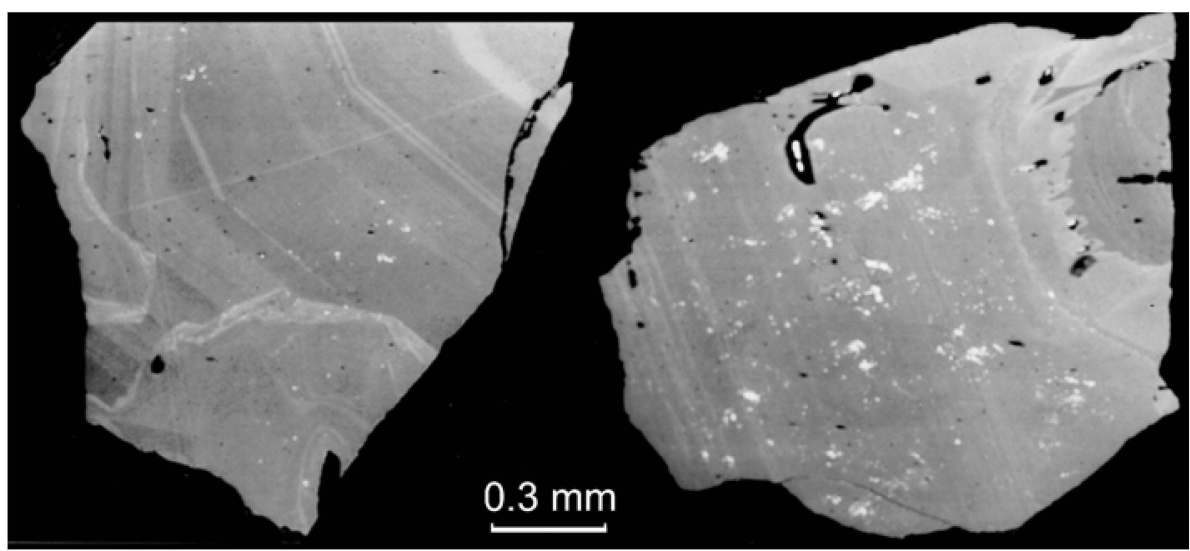

FIG. 6. SEM image (backscattered electrons) of growth zoning in Delbegetey emerald crystals. Both straight line and irregular zones can be observed in both samples. Bright particles, abundant in the right sample correspond to mineral inclusions (mostly rutile). 


\section{Fluid inclusions}

Microscopic study of polished plates and faceted stones revealed the presence of different fluid inclusion (FI) types in the emeralds studied. As regards morphology and position of FI assemblages, the following types of inclusions were found:

P1 - primary fluid inclusions, elongated parallel to the $c$ axis, sometimes exhibiting a negative crystal shape (Fig. 7). These inclusions are strongly controlled by growth zones parallel to pinacoid faces, and sometimes associate with particles of trapped mineral inclusions (partly corroded, minute mica platelets).

P2 - single large vacuoles of irregular form, spatially tending to superficial zones of crystals. Inclusions of this type are also primary but different from P1 above, possibly formed later.

PS1 - fluid inclusion assemblages formed in healed fractures, coinciding with pinaciod planes of crystals. Some of these are elongated perpendicular to the $c$ axis of the crystal.

PS2 - these are similar to the PS1 type, differentiated by the orientation of healed fractures, parallel to the $c$ axis of crystal in this case. Some fluid inclusions are oriented parallel to the $c$ axis.

PS3 - healed fractures with no special crystallographic orientation, cutting growth zones of crystals. They usually have irregular forms, without marked elongation, and are confined to the healed fracture orientation. Some irregularly orientated fractures with fluid inclusions parallel to the $c$ axis were also observed (Fig. 8).

Inclusions of the last three types were classified as pseudosecondary fluid inclusions due to the similarity in the phase-filling and microthermometric data obtained for them with those obtained for clearly primary inclusions. It may be that the formation of all healed fractures and PS1-PS3 fluid inclusions took place during crystal formation, or, possibly, after that, but under very similar $P-T$ conditions.

As regards phase filling, fluid inclusions of all types present very similar composition, with liquid (L) and vapour (V) phases present at room-temperature conditions, and $\mathrm{L}: \mathrm{V}$ ratios ranging from $40: 60$ to $10: 90$. Inclusions with daughter minerals were not observed in the

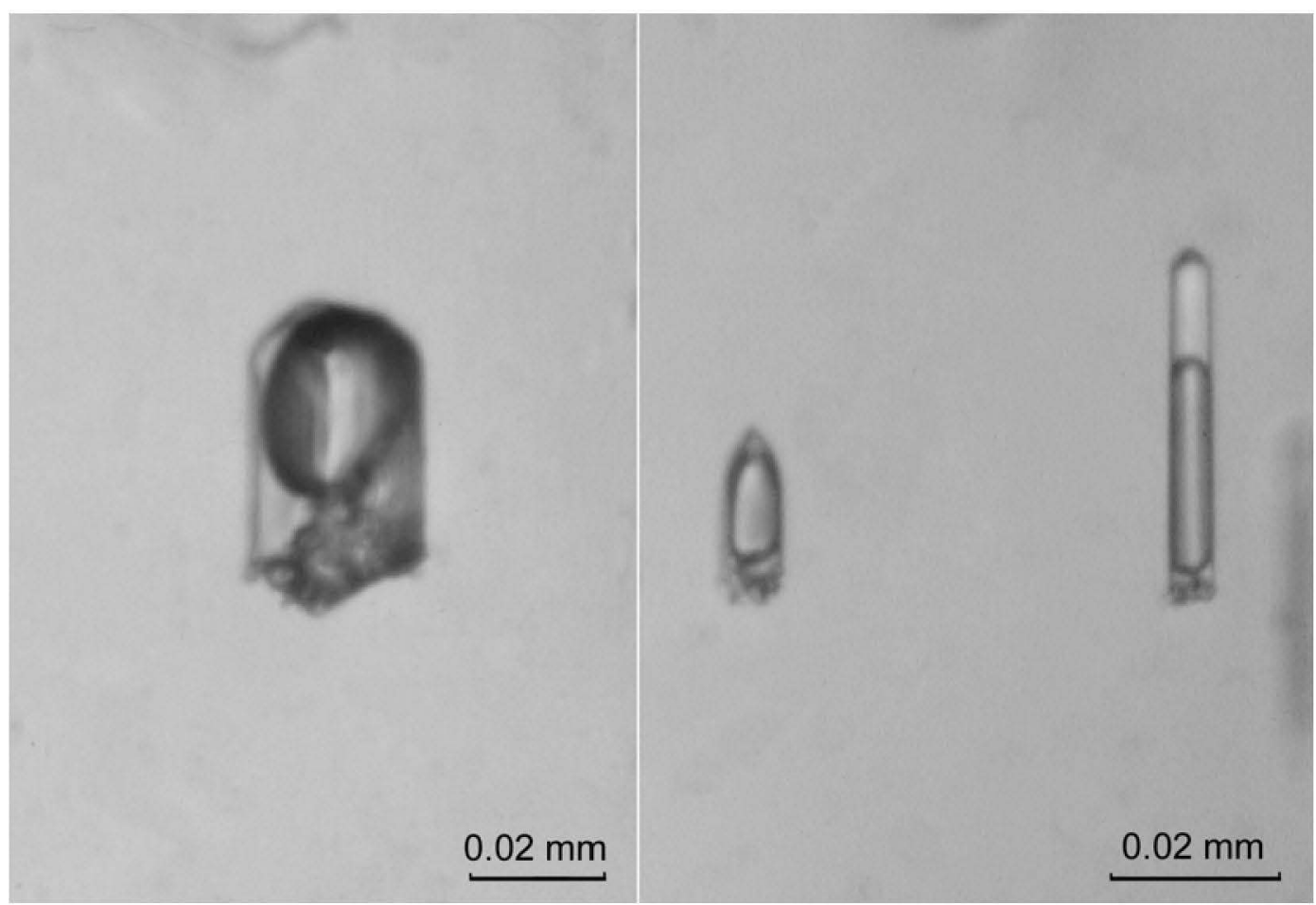

Fig. 7. Primary fluid inclusions (P1-type) situated on trapped mineral particles. 

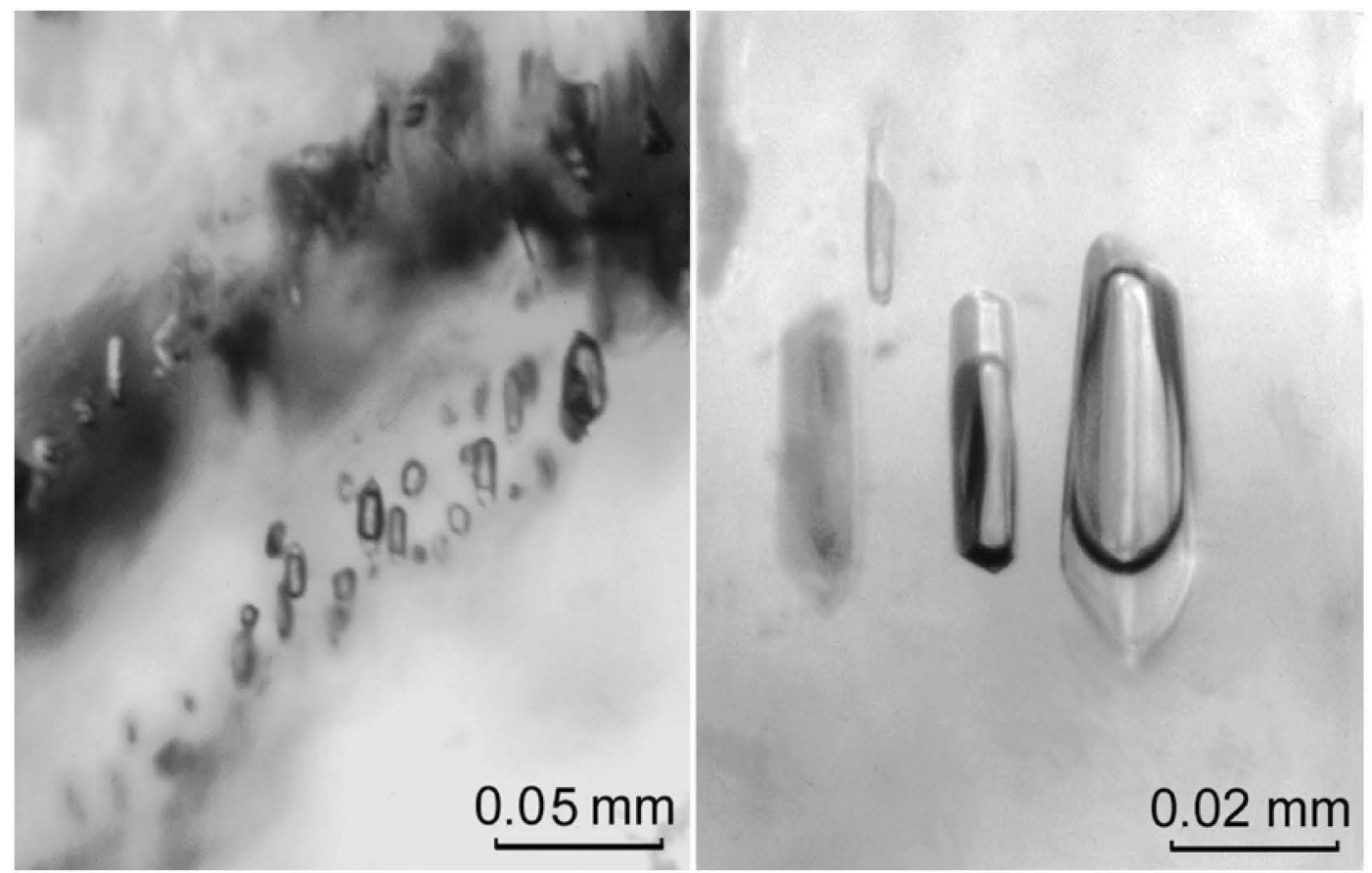

FIG. 8. Pseudosecondary fluid inclusions (PS3-type) in Delbegetey emeralds.

Delbegetey samples. Some inclusions contain minute particles of trapped crystals. The volume of these solid phases is not consistent within the same fluid inclusion assemblage, and they do not dissolve while heating up to the total homogenization of aqueous and vapour phases.

Liquid $\mathrm{CO}_{2}$ was not observed at room-temperature conditions in fluid inclusions of any type. In the majority of fluid inclusions of all types, the presence of liquid $\mathrm{CO}_{2}$ was not observed, even during the cooling of inclusions. Ice melting and total homogenization temperatures were measured for these inclusions. Nevertheless, during the cooling experiments, in three fluid inclusion assemblages, a minute liquid $\mathrm{CO}_{2}$ meniscus appeared, and the temperatures of $\mathrm{CO}_{2}$ melting, clathrate melting and $\mathrm{CO}_{2}$ homogenization could be also measured for these inclusions. It is important to note that no relationship between the type of FI assemblage and the presence of liquid $\mathrm{CO}_{2}$ was observed. In two similar FI assemblages, situated in the same crystal (P1type, clearly primary inclusions), only in one was liquid $\mathrm{CO}_{2}$ observed while cooling. The other showed typically aqueous behaviour. Similarly, only in one of the four pseudosecondary PS2-type
FI assemblages studied was liquid $\mathrm{CO}_{2}$ present. This phenomenon may be explained by the changing $\mathrm{CO}_{2}$ concentrations in the fluids during emerald crystal formation.

Microthermometric measurements were taken from 64 fluid inclusions belonging to nine FI assemblages of different types (Table 3 ). To calculate fluid properties, the $B U L K$ computer program (Bakker, 2003) was used. For aqueous fluid inclusions, salinity was calculated using the melting temperature of ice (Archer, 1992), and bulk density using the Zhang and Frantz (1987) equation of state. Aqueous-carbonic inclusions present $\mathrm{CO}_{2}$ melting temperatures between 56.6 and $56.9^{\circ} \mathrm{C}$, very close to those of pure $\mathrm{CO}_{2}$, slightly lower due to the presence of other gases, possibly $\mathrm{CH}_{4}$, typical of emerald-forming fluids of other deposits (Abdalla and Mohamed, 1999; Fuertes-Fuente et al., 2000; Vapnik et al., 2005). Possible concentrations of $\mathrm{CH}_{4}$ were calculated for these inclusions on the basis of $\mathrm{CO}_{2}$ melting and homogenization temperatures (Heyen et al., 1982; Shepherd et al., 1985). The density of a non-aqueous phase was calculated via the Duan et al. (1992) equation of state. The salinity of the aqueous phase of carbonic-bearing inclusions was 
calculated using chlatrate melting temperatures (Darling, 1991). The results of fluid properties calculations are shown in Table 3.

Figure 9 shows isochores calculated for all FI assemblages studied. Isochores were calculated using the ISOC computer program (Bakker, 2003), based on different equations of state for aqueous (Knight and Bodnar, 1989; Bodnar and Vityk, 1994) and aqueous-carbonic (Bowers and Helgeson, 1983; Bakker, 1999) inclusions. Calculated isochores for inclusions of all types, both those of aqueous and aqueous-carbonic inclusions, belong to a quite narrow $P-T$ region, possibly indicating the similarity of entrapment conditions of primary and pseudosecondary inclusions of different types. Some suggestions as to emerald formation conditions, based on calculated isochores, are made in the discussion.

\section{Mineral inclusions}

The crystals studied, in general, are very pure in mineral inclusions. The most common inclusion observed was minute, partly-corroded, brown biotite platelets. One sample further contains linear zones with numerous inclusions of other highly refractive minerals. The SEM-EDS study of this sample allowed us to identify these inclusions as rutile, with large amounts of $\mathrm{W}, \mathrm{Cr}$ and $\mathrm{Fe}$ (up to 6.18 wt.\% $\mathrm{WO}_{3}, 4.17$ wt.\% $\mathrm{Cr}_{2} \mathrm{O}_{3}$ and 1.67 wt. $\% \mathrm{Fe}_{2} \mathrm{O}_{3}$, with very heterogeneous distribution observed in backscattered electrons), and monazite-(Ce).

\section{Discussion}

The study of the physical properties of the Delbegetey samples reveals some characteristics usually atypical of natural emeralds. Very low refractive indices can by explained by the very pure chemical composition of the samples studied. According to Černý and Hawthorne (1976), the refractive indices of beryl can increase, among other reasons, because of the entrance of large alkali ions into the structure channels of beryl, as a result of $\mathrm{Al}^{3+}$ substitution by other trivalent ions (mainly $\mathrm{Fe}^{3+}, \mathrm{Cr}^{3+}$ and $\mathrm{V}^{3+}$ ) with large atomic numbers, and because of the presence of molecular water in the structure channels. The influence of water quantities on refractive indices was also demonstrated by the experimental study of synthetic beryls, carried out by Pankrath and Langer (2002). The low refractive indices of the samples studied are in agreement with their pure chemical composition, and also point to the relatively small amount of channel water present in the emeralds studied.

As regards the small specific gravity values, these may also be explained by the purity of chemical composition and, most importantly, by

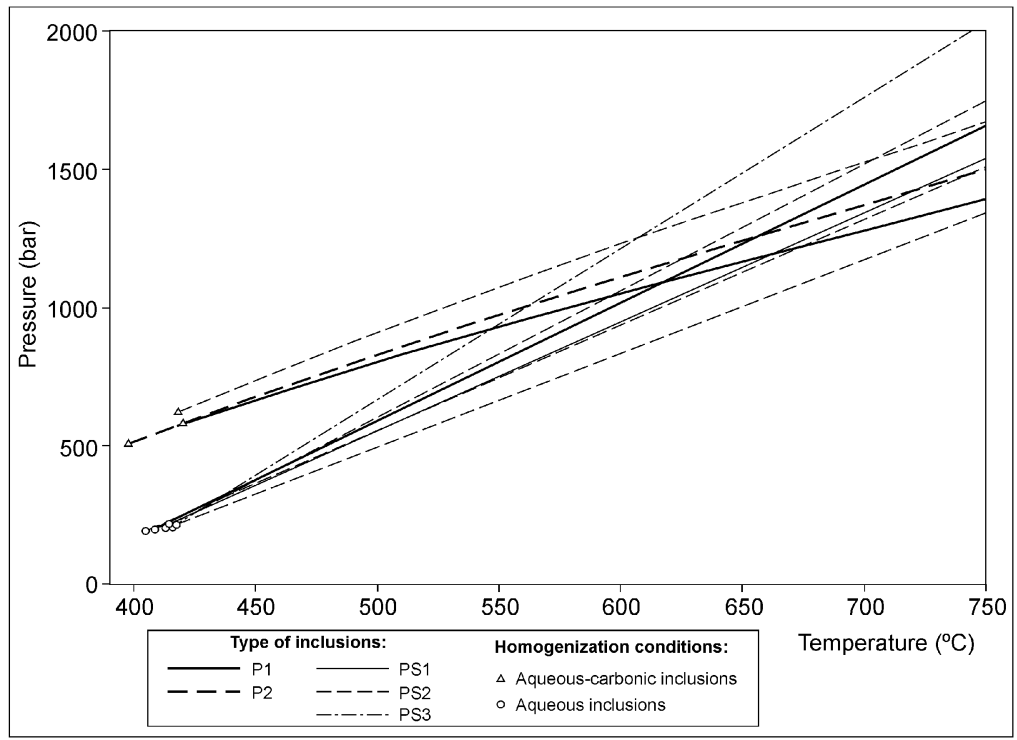

FIG. 9. Isochores calculated for fluid inclusion assemblages of different types. 
the presence of a large number of large, lowdensity inclusions, filled mainly by the vapour phase.

Regarding optical absorption, the emeralds studied present typical $\mathrm{Cr}^{3+}$ emerald spectra, with some quantities of bivalent $\mathrm{Fe}$. A V component, possibly present in the samples studied, is masked by $\mathrm{Cr}$ in the spectra. The presence of broad absorption in the near IR area, typical of natural emeralds from several deposits (Schwarz, 2002) is also noted in our spectra.

As regards the colouring agents of the emeralds studied, it is noteworthy that some Delbegetey samples contain $\mathrm{V}_{2} \mathrm{O}_{3}$ which, in a few samples, exceeds the amount of $\mathrm{Cr}_{2} \mathrm{O}_{3}$ present. Nevertheless, $\mathrm{Cr}$ still seems to be the principal colouring element, together with $\mathrm{Fe}$, given that the maximum and the average values of $\mathrm{Cr}_{2} \mathrm{O}_{3}$ are much greater than those of $\mathrm{V}_{2} \mathrm{O}_{3}$. The plot of emerald composition in terms of $\mathrm{FeO}-\mathrm{Cr}_{2} \mathrm{O}_{3}-$ $\mathrm{V}_{2} \mathrm{O}_{3}$ (Fig. 4) also supports this assertion. Some $\mathrm{Fe}$ is present in all the microprobe analyses of the Delbegetey samples. The optical absorption spectra suggest a bivalent nature for the $\mathrm{Fe}$ in the samples studied. It is possible that this component also acts as a chromophore for these emeralds, being responsible for their slightly bluish hue.

Earlier emerald chemistry studies (e.g. by Hänni, 1982; Schwarz, 1992; Moroz and Eliezri, 1998) show that the major trace elements in natural emeralds are $\mathrm{Mg}, \mathrm{Na}, \mathrm{Fe}, \mathrm{Cr}$ and, in some deposits, $\mathrm{V}$, whereas other elements are usually present in lesser concentrations. Synthetic emeralds, both flux-grown and hydrothermal, are generally purer than those occurring in nature (Hänni, 1982; Stockton, 1984). The results of the present comparative study of emerald chemical composition are consistent with these observations (Table 2). The larger amounts of $\mathrm{Fe}$ (up to $2.73 \mathrm{wt} . \% \mathrm{FeO}$ ) in the hydrothermal synthetic emeralds studied is explained by the growth process in steel autoclaves.

It is noteworthy that the concentrations of major trace elements, such as $\mathrm{Na}, \mathrm{Mg}$ and $\mathrm{Fe}$, are very low in the Delbegetey emeralds, in comparison with other natural samples. Given such pure chemical composition, the points corresponding to Delbegetey emeralds fall within the area of low octahedral impurity concentrations, and large $\mathrm{Al}$ contents in Fig. 5, close to very pure synthetic flux-grown emeralds.

According to the crystal chemical classification of Aurisicchio et al. (1988), the Delbegetey samples studied can be classified as 'normal' beryls, in which there is not a large amount of metals which isomorphously replace $\mathrm{Al}^{3+}$; nor is there much substitution of $\mathrm{Be}^{2+}$ by $\mathrm{Li}^{+}$in tetrahedral sites. These beryls may reveal some isomorphous substitutions of both types, though to a limited extent. The ratio of lattice parameters $c / a$ obtained for the Delbegetey emeralds (0.998) corresponds to the range of $c / a$ ratios characteristic of 'normal' beryls: 0.997-0.999 (Aurisicchio et al., 1988). Beryls of this type have large $\mathrm{Al}$ (1.9 a.p.f.u. or more) and $\mathrm{Be}$ contents, near stoichiometric values. Emeralds of other origins usually have smaller Al contents, normally between 1.5 and 1.9 a.p.f.u., with the exception of Colombian emeralds (Groat $e t$ al., 2002).

With regard to the fluid inclusions in the emeralds studied, the large volume of vapour phase in the filling of primary and pseudosecondary inclusions is noteworthy. This is unusual for emeralds from other deposits, which normally contain a greater proportion of liquid phase (Grundmann and Morteani, 1989; Nwe and Grundmann, 1990; Cheilletz et al., 1994; Gavrilenko et al., 2001; Groat et al., 2002; Marshall et al., 2004). According to microthermometric data, all fluid inclusion assemblages may correspond to the same stage of fluid circulation, responsible for emerald mineralization.

Unfortunately, there are no additional independent data available to estimate real FI entrapment temperature and/or pressure. The lower $P-T$ limit of emerald formation conditions is marked by the highest homogenization temperature and pressure observed for clearly primary fluid inclusions $\left(416^{\circ} \mathrm{C}, 568\right.$ bar). As regards higher limits of possible emerald formation $P-T$ range, we suggest that the temperatures of emerald mineralization may be similar to those reported for numerous granitic magmatism-related emerald deposits worldwide (Nwe and Morteani, 1993; Laurs and Dilles, 1996; Abdalla and Mohamed, 1999; Fuertes-Fuente et al., 2000; Aleksandrov et al., 2001; Gavrilenko et al., 2001; Moroz et al., 2001; Groat et al., 2002; Vapnik and Moroz, 2002), and these do not normally exceed $500-550^{\circ} \mathrm{C}$. These data agree with maximum temperatures usually used for hydrothermal synthesis of emeralds $\left(600^{\circ} \mathrm{C}\right.$, Nassau, 1980$)$. Using this temperature as a putative maximum temperature of emerald formation, and given the isochores calculated (Fig. 9), the maximum pressure of Delbegetey emerald formation may be estimated as 1240 bar. 
With regard to mineral inclusions, while biotite and rutile are very common as inclusions in emeralds from other emerald deposits (Shwarz, 1987; Schwarz, 1994; Moroz and Eliezri, 1999), the presence of monazite-(Ce) inclusions, to the best of our knowledge, has not been reported in other natural emeralds. On the other hand, the presence of this mineral, typical of granites, seems quite normal in metasomatic emerald deposits.

\section{Conclusions}

The general geological setting and the oxygen isotope composition, allow us to classify the Delbegetey emeralds as a typical metasomatic granite-related emerald deposit. Nevertheless, it is located in sedimentary rocks, quite atypical for deposits of this type which are normally situated in magmatic or metamorphic $\mathrm{Cr} / \mathrm{V}$-bearing host rocks.

The study of fluid inclusions allows us to estimate the range of $P-T$ conditions for Delbegetey emerald formation at between $420-600^{\circ} \mathrm{C}$ and $570-1240$ bar. The unusual geological setting and, probably, quite shallow depths of formation, had some important consequences for the morphological and physical properties of emeralds found at this locality. These include the following:

(1) dissolution forms on crystal faces atypical of emeralds from other metasomatic deposits;

(2) a bluish-green colour, and a distinctive colour zoning;

(3) relatively small refractive indices and specific gravity values;

(4) a very pure chemical composition and the presence of both $\mathrm{Cr}$ and $\mathrm{V}$, besides $\mathrm{Fe}$, as chromophores;

(5) a significant preponderance of vapour in fluid inclusions of all types, and liquid to vapour homogenization of primary fluid inclusions.

The presence of these characteristic features facilitates the simple and unequivocal distinction between Delbegetey emeralds and those from other natural and synthetic origins, whether they be rough or faceted stones.

\section{Acknowledgements}

The authors are grateful to E.A. Vinogradova for kindly donating the emerald samples for this study. We thank G. Giuliani and N.P. Stepanov for their help in obtaining oxygen isotope compositions and X-ray diffraction data respectively. The support of projects GR92-0135, UE950007 and UE98-0027 from the Spanish Ministry of Education and Culture (MEC) and FEDER/EU (1999) for the equipment used is also acknowledged.

\section{References}

Abdalla, H.M. and Mohammed, F.H. (1999) Mineralogical and geochemical investigation of emerald and beryl mineralization, Pan-African Belt of Egypt: genetic and exploration aspects. Journal of African Earth Sciences, 28, 581-598.

Alexandrov, P., Giuliani, G. and Zimmermann, J.-L. (2001) Mineralogy, age and fluid geochemistry of the Rila Emerald deposit, (Bulgaria). Economic Geology, 96, 1469-1476.

Archer, D.G. (1992) Thermodynamic properties of the $\mathrm{NaCl}+\mathrm{H}_{2} \mathrm{O}$ system: II. Thermodynamic properties of $\mathrm{NaCl}(\mathrm{aq}), \mathrm{NaCl} \cdot 2 \mathrm{H}_{2} \mathrm{O}(\mathrm{cr}$ ), and phase equilibria. Journal of Physical and Chemical Reference Data, 28, 1-17.

Aurisicchio, C., Fioravanti, G., Grubessi, O. and Zanazzi, P.F. (1988) Reappraisal of the crystal chemistry of beryl. American Mineralogist, 73, 826-837.

Bakker, R.J. (1999) Adaptation of the Bowers and Helgeson (1983) equation of state to the $\mathrm{H}_{2} \mathrm{O}-\mathrm{CO}_{2-}$ $\mathrm{CH}_{4}-\mathrm{N}_{2}-\mathrm{NaCl}$ system. Chemical Geology, 154, 225-236.

Bakker, R.J. (2003) FLUIDS 1. Computer programs for analysis of fluid inclusions data and for modelling bulk fluid properties. Chemical Geology, 194, 3-23.

Bodnar, R.J. and Vityk, M.O. (1994) Interpretation of microthermometric data for $\mathrm{H}_{2} \mathrm{O}-\mathrm{NaCl}$ fluid inclusions. Pp. 117-130 in: Fluid Inclusions in Minerals: Methods and Applications (B. de Vivo and M.L. Frezzotti, editors). IMA Short Course.

Bowers, T.S. and Helgeson, H.C. (1983) Calculation of the thermodynamic and geochemical consequences of non-ideal mixing in the system $\mathrm{H}_{2} \mathrm{O}-\mathrm{CO}_{2}-\mathrm{NaCl}$ on phase relations in geologic systems: Equation of state for $\mathrm{H}_{2} \mathrm{O}-\mathrm{CO}_{2}-\mathrm{NaCl}$ fluids at high pressures and temperatures. Geochimica et Cosmochimica Acta, 47, 1247-1275.

Černý, P. and Hawthorne, F.C. (1976) Refractive indexes versus alkali contents in beryl; general limitations and applications to some pegmatite types. The Canadian Mineralogist, 14, 491-497.

Cheilletz, A., Féraud, G., Giuliani, G. and Rodriguez, C.T. (1994) Time-pressure and temperature constraints on the formation of Colombian emeralds: An $\mathrm{Ar}^{40} / \mathrm{Ar}^{39}$ laser microprobe and fluid inclusion study. Economic Geology, 89, 361-380.

Clayton, R.N. and Mayeda, T.K. (1963) The use of the 
bromine pentafluoride in the extraction of oxygen from oxides and silicates for isotopic analysis. Geochimica et Cosmochimica Acta, 27, 32-45.

Darling, R.S. (1991) An extended equation to calculate $\mathrm{NaCl}$ contents from final clathrate melting temperatures in $\mathrm{H}_{2} \mathrm{O}-\mathrm{CO}_{2}-\mathrm{NaCl}$ fluid inclusions: Implications for P-T isochore location. Geochimica et Cosmochimica Acta, 55, 3869-3871.

Duan, Z., Moller, N. and Weare, J.H. (1992) An equation of state for the $\mathrm{CH}_{4}-\mathrm{CO}_{2}-\mathrm{H}_{2} \mathrm{O}$ system: I. Pure systems from 0 to $1000^{\circ} \mathrm{C}$ and 0 to 8000 bar. Geochimica et Cosmochimica Acta, 56, 2605-2617.

Fuertes-Fuente, M., Martin-Izard, A., Boiron, M.C. and Mangas Viñuela, J. (2000) P-T path and fluid evolution of the Franqueira granitic pegmatite, central Galicia, northwestern Spain. The Canadian Mineralogist, 38, 1163-1175.

Gavrilenko, E.V. and Dashevsky, D.M. (1998) Properties of emeralds of different genesis and their diagnostic meaning. Proceedings of the Russian Mineralogical Society, 127, 47-57 (in Russian).

Gavrilenko, E.V., Giuliani, G., Popov, M. and FranceLanord, Ch. (2001) Emeralds of the Ural mountains (Russia): Geology, fluid inclusions and oxygen isotopes. XXVIII International Gemmological Conference, Madrid, October 2001, Instituto Gemológico Español, pp. 36-40.

Giuliani, G., France-Lanord, Ch., Coget, P., Cheilletz, A., Branquet, Y., Giard, D., Martin-Izard, A., Alexandrov, P. and Piat, D.H. (1998) Oxygen isotope systematics of emeralds: relevance for its origin and geological significance. Mineralium Deposita, 33, 513-519.

Groat, L.A., Marshall, D.D., Giuliani, G., Murphy, D.C., Piercey, S.J., Jambor, J.L., Mortensen, J.K., Ercit, T.S., Gault, R.A., Mattey, D.P., Schwartz, D., Maluski, H., Wise, M.A., Wengzynowski, W. and Eaton, D.W. (2002) Mineralogical and geochemical study of the Regal Ridge emerald showing, Southern Yukon. The Canadian Mineralogist, 40, 1313-1338.

Grundmann, G. and Morteani, G. (1989) Emerald mineralization during regional metamorphism: The Habachtal (Austria) and Leydsdorp (Transvaal, South Africa) deposits. Economic Geology, 84, 1835-1849.

Hänni, H.A. (1982) A contribution to the separability of natural and synthetic emeralds. Journal of Gemmology, 18, 138-143.

Heyen, G., Ramboz, C. and Dubessy, A. (1982) Simulation des équilibres de phases dans le systéme $\mathrm{CO}_{2}-\mathrm{CH}_{4}$ en dessous de $50^{\circ} \mathrm{C}$ et de 100 bar. Application aux inclusions fluides. (Phase equilibrium simulation in the system $\mathrm{CO}_{2}-\mathrm{CH}_{4}$ below $50^{\circ} \mathrm{C}$ and 100 bar. Application to the fluid inclusions.) Comptes Rendus de l'Académie des Sciences de Paris, 294, 203-206.
Knight, C.L. and Bodnar, R.J. (1989) Synthetic fluid inclusions: IX. Critical PVTX properties of $\mathrm{NaCl}-\mathrm{H}_{2} \mathrm{O}$ solutions. Geochimica et Cosmochimica Acta, 53, 3-8.

Laurs, B.M., Dilles, J.H. and Snee, L.W. (1996) Emerald mineralization and metasomatism of amphibolite, Khaltaro granitic pegmatite - hydrothermal vein system, Haramosh Mountains, Northern Pakistan. The Canadian Mineralogist, 34, 1253-1286.

Marshall, D.D., Groat, L.A., Falck, H., Giuliani, G. and Neufeld, H. (2004) The Lened emerald prospect, Northern Territories, Canada: Insights from fluid inclusions and stable isotopes, with implications for Northern Cordilleran emeralds. The Canadian Mineralogist, 42, 1523-1539.

Moroz, I.I. and Eliezri, I.Z. (1998) Emerald chemistry from different deposits. Australian Gemmologist, 20, 64-69.

Moroz, I.I. and Eliezri, I.Z. (1999) Mineral inclusions in emeralds from different sources. Journal of Gemmology, 26, 6, 357-363.

Moroz, I., Vapnik, Y., Eliezri, I. and Roth, M. (2001) Mineral and fluid inclusion study of emeralds from the Lake Manyara and Sumbawanga deposits, Tanzania. Journal of African Earth Sciences, 33, 377-390.

Munsell, A.H. (1988) A Color Notation, $15^{\text {th }}$ edition. Munsell Color Company, Baltimore, Maryland, USA, $67 \mathrm{pp}$.

Nassau, K. (1980) Gems Made by Man. Chilton Book, Randor, Pennsylvania, USA, 364 pp.

Nwe, Y.Y. and Grundmann, G. (1990) Evolution of metamorphic fluids in shear zones: The record from the emeralds of Habachtal, Tauern Window, Austria. Lithos, 25, 281-304.

Nwe, Y.Y. and Morteani, G. (1993) Fluid evolution in the H2O-CH4-CO2- $\mathrm{NaCl}$ system during emerald mineralization at Gravelotte, Murchison Greenstone Belt, North-East Transvaal, South Africa. Geochimica et Cosmochimica Acta, 57, 89-103.

Pankrath, R. and Langer, K. (2002) Molecular water in beryl, ${ }^{\mathrm{V}} \mathrm{Al}_{2}\left[\mathrm{Be}_{3} \mathrm{Si}_{6} \mathrm{O}_{18}\right] \cdot \mathrm{nH}_{2} \mathrm{O}$, as a function of pressure and temperature: An experimental study. American Mineralogist, 87, 238-244.

Schwarz, D. (1987) Esmeraldas - Inclusoes em gemas. Universidad Federal de Ouro Preto, Imprensa Universitaria, Ouro Preto, Brazil, 439 pp.

Schwarz, D. (1992) The chemical properties of Colombian emeralds. Journal of Gemmology, 23, 225-233.

Schwarz, D. (1994) Emeralds from the Mananjary Region, Madagascar: Internal Features. Gems and Gemology, 30, 88-101.

Schwarz, D. (2002) Gemology of emerald. Pp. 66-71 in: Emeralds of the World. (G. Giuliani et al., editors). ExtraLapis English, 2. 
Shepherd, T.J., Rankin, A.H. and Alderton, D.H.M. (1985) A Practical Guide to Fluid Inclusion Studies. Blackie, Glasgow and London, $239 \mathrm{pp}$.

Sheppard, S.M.F. (1986) Characterisation and isotopic variations in natural waters. Pp. 165-183 in: Stable Isotopes in High Temperature Geological Processes (J.W. Valley, H.P. Taylor, Jr. and J.R. O'Neil, editors). Reviews in Mineralogy and Geochemistry, 16. Mineralogical Society of America, Washington, D.C.

Stockton, C.M. (1984) The chemical distinction of natural from synthetic emeralds. Gems and Gemology, 20, 141-145.

Vapnik, Ye. and Moroz, I. (2002) Compositions and formation conditions of fluid inclusions in emerald from the Maria Deposit (Mozambique). Mineralogical Magazine, 66, 201-213.

Vapnik, Ye., Sabot, B. and Moroz, I. (2005) Fluid inclusions in Ianapera emerald, Southern Madagascar. International Geology Review, 47, $647-662$.
Vinogradova, E.A. (head of the project) (1996) Determination of main objects for precious stones prospecting in the Republic of Kazakhstan, with the selection of areas for special geological-mineralogical mapping on a scale of 1:200.000. Report of the works from the period 1995-96. Archives of the Ministery of Geology of Kazakhstan Republic, Mirniy (in Russian).

Wood, D.L. and Nassau, K. (1968) The characterization of beryl and emerald by visible and infrared absorption spectroscopy. American Mineralogist, 53, 777-800.

Zhang, Y.G. and. Frantz, J.D (1987) Determination of the homogenization temperatures and densities of supercritical fluids in the system $\mathrm{NaCl}-\mathrm{KCl}-\mathrm{CaCl}_{2}-$ $\mathrm{H}_{2} \mathrm{O}$ using synthetic fluid inclusions. Chemical Geology, 64, 335-350. 